\title{
STATUTE LAW AND THE OWL OF MINERVA: THE BILLS OF EXCHANGE ACT, 1882
}

\author{
JANICE DICKIN MCGINNIS*
}

\begin{abstract}
This article examines the legal and economic history of the Bills of Exchange Act, 1882. The author describes the types of transactions giving rise to the concept of the bill of exchange, reviews the statute's codification of the common law, and addresses the question of reform in the modern commercial setting.
\end{abstract}

\section{INTRODUCTION}

According to Hegelian philosophy, as humans we are incapable of understanding any process we are caught up in until it is nearly played out: the owl of Minerva flies out at the coming of the dusk.' This theory readily brings forward two thoughts about the viability of statute law. One is that statutes meant to force change are likely to fail or succeed for reasons having to do only tangentially with legislative intent. The other is that statutes meant to codify long-standing custom are liable to early obsolescence. Creatures of inexorable change, codifying statutes are not, in the end, capable of resisting change. Legal arguments based upon them become increasingly ritualistic. Like the telling of a well-worn rosary, this may be acceptable practice but there is little health in it.

Modern conventional wisdom regarding the Bills of Exchange Act is that any lawyer understanding it can build his/her fortune upon the having of so rare a knowledge. It is little wonder that the legal community should be confused by this statute. Bills of exchange are items of commercial paper that really did not survive the Second World War. Their closest extant relation of any importance is the cheque, a far less ambitious instrument that tagged on the shirt-tails of bills of exchange and, now alone, is rapidly shedding the trappings of negotiability, the major legal concept that the Bills of Exchange Act was set up to enshrine. A distinguished piece of legislation articulating half a millenium of European commercial practice has been emasculated by two world wars, shifts in world trade practices, the rise of banks and, most recently, by the computer.

This is not to say that we will never, as modern lawyers, come into contact with a negotiable instrument falling under the statutory protection codified in the original British Bills of Exchange Act, 1882 (45 \& 46 Vict., c. 61$).{ }^{2}$ But what we will be dealing with is a new type of commercial paper which looks much more like a negotiated contract than a slip of negotiable commercial currency. It is possible to make the new bills fit with the old statute - indeed they are carefully drafted so to do by fellow lawyers - but the logic will not always be clear. As Edward H. Levi has

I wish to thank Prof. Chris Levy of the Faculty of Law, University of Calgary for agreeing to supervise my research on Bills of Exchange as a course substitute and also Dr. David P. McGinnis of the Department of History, University of Calgary for long-term instruction in the field of economic history.

- Articling Student, Burnet, Duckworth \& Palmer in Calgary.

1. Charles Taylor, Hegel and Modern Society (Cambridge: Cambridge University Press, 1979), p. 122.

2. As currently enacted in Canada under Bills of Exchange Act. RSC (1970) c. B-5, RSC, c. 15. 
commented regarding the mutation of legal terminology, "the word starts out to free thought and ends by enslaving it". ${ }^{3}$ This paper is not a plea for the revision or abolition of legislation regarding negotiable instruments. Rather, it is an attempt to give us all a better understanding of where we have fetched up by showing where we have been. The purpose of progressive historical writing is never to fix past events in some sort of tableau like flies in amber but to reveal to us an ongoing process which has us in its clutches. In this way we may at least recognize when it is time for the goddess of knowledge to let loose another of her owls.

The paper will follow a topical format. I would like first to get the account of the codification itself out of the way before dealing with the legal history in back of it and, more importantly, the economic history surrounding it. I will then discuss briefly the heritage left by the Act in terms of legal formalism. The conclusion will also include reference to modern-day calls to reform or repeal the statute.

\section{AN EXPERIMENT IN CODIFICATION}

The title of this section comes from an article published in the Law Quarterly Review in 1886.4 The author is Mackenzie Dalzell Chalmers, by then 39 years of age, late of the Indian Civil Service, second child of an Anglican clergyman, author of $A$ Digest of the Laws of Bills of Exchange (1878) and of the Bills of Exchange Act (1882), and the future author of the Sale of Goods Act (1894) and the Marine Insurance Act (1906). In addition to endearing himself to following generations of law students in making good despite the fact that he took only a pass degree from Trinity College at Oxford, ${ }^{5}$ Chalmers displayed an elegant literary style in what he has left for us to read. He is as capable as any other nineteenth century jurist of pointless ramblings in Latin but at the same time, has the humor to sum up his philosophy of the common law in a line from a popular song: "love your neighbour as yourself, and paddle your own canoe' "'.6 Miraculously, Chalmers' elegance and humor follow him even into the jaws of codification. If one looks at the Bills of Exchange Act solely within the commercial context of the mid-1800s and appreciates it as a method of ensuring merchants of their own form of short-term credit, one is forced to admire his achievement. But perhaps the better example of his style now, though less ambitious and accomplished, is the Sale of Goods Act which has dated less drastically.

Chalmers' accomplishment lies not only in the drafting of the Bills of Exchange Act but in the fact that it was the first enactment by Britain of a codification of its common law. No previous statute was meant to write down the law as it had been evolved in the courts and by enactments of Parliament. Other attempts at codification were also in the air, most notably the criminal law according to Sir Fitz-James Stephens (never

3. An Introduction to Legal Reasoning (Chicago and London: University of Chicago Press, 1949), p. 8.

4. Mackenzie D. Chalmers, "An Experiment in Codification" (1886) 6 Law Quarterly Review 125.

5. See J.R.H. Weaver, ed., The Dictionary of National Biography, 1922-1930 (London: Oxford University Press, 1937), p. 166-8.

6. Supra n. 4, p. 131 . 
enacted) and the law of partnership according to Sir Frederick Pollock (enacted 1890). Of no doubt more direct influence on Chalmers was the codification in India of a Penal Code, Evidence Act and Contracts Act, all set on paper by Thomas Macaulay (later Baron Macaulay of Rothley), through the influence of Jeremy Bentham. Following the trend, the Indian Law Commission drafted a code for negotiable instruments in 1866 and put it out for discussion. Chalmers' stint in the Indian Civil Service (1869-71) came at precisely this time and the Indian Negotiable Instruments Act predates his own by only one year. ${ }^{7}$

It is fortunate that we have Chalmers' own account of the codification of bills of exchange: Hansard offers us little. After the (as usual) perfunctory first reading on 15 February 1882 , Bill 70 was introduced for its second reading five days later by Sir John Lubbock who was, significantly, President of the Institute of Bankers ${ }^{8}$ and who stressed ${ }^{9}$

... that its object was simply to codify and consolidate the law relating to bills of exchange and promissory notes. It contained no new provisions; but it was a measure of great importance to mercantile men, for at present the law was scattered through some 20 Acts of Parliament, and nearly 3,000 legal decisions contained in law reports. Mercantile men were anxious that the law upon these subjects should be brought into a more convenient and accessible form. The Bill had been drafted by the Council of the Associated Chambers of Commerce and the Institute of Bankers, and was supported by the Society of Notaries.

From there, Bill 70 went for consideration by a Select Committee on the Bills of Exchange Bill, chaired by Lubbock and attended over its ten days of meetings by Chalmers himself (at a handsome fee of $£ 52$ 10s. Od.). The committee went through the bill clause by clause and, after a decision was made to make the bill also apply to Scotland, made necessary changes to embrace the different legal system there. The report of the committee is distinctly unrevealing, no more than a list of committee members, dates met, sections considered. ${ }^{10} \mathrm{We}$ do, however, have indications of the process followed from other sources. It would seem that the changes made were in form rather than in substance. As one Scottish jurist commented owlishly regarding the decision to extend the bill to Scotland, "many of the sections were expressed in technical language, which tended to obscure its meaning to Scotch lawyers, and to throw difficulties in the way of its being understood by merchants and bankers on either side of the Tweed"." The revised bill was introduced into the House of Lords by the Lord Chancellor (Selborne) on 25 July 1882, received slight further amendment at the hands of a Select Committee of the House of Lords,

7. M.J.L. Rajanayagam, The Law Relating to Negotiable Instruments in Australia (Sydney: Butterworths, 1980), p. 4.

8. Mackenzie D. Chalmers, A Digest of the Law of Bills of Exchange, Promissory Notes, Cheques, and Negotiable Securities (6th ed.; London: Stevens and Sons, 1903), Introduction to 3rd edition, p. xlvi.

9. Great Britain, Parliamentary Debates, 1882 (3rd series), vol. 266, p. 1202.

10. Report from the Select Committee on the Bills of Exchange Bill; with the proceedings of the Committee. Parliamentary Papers 1882 (244) vii, 585-92.

11. W.D. Thorburn, Commentary on the Bills of Exchange Act, 1882 (Edinburgh: Bell and Bradfute, 1882), p. iii. 
was passed without opposition and came into operation on 18 August 1882.12

It is to Chalmers' account of the process that we must turn for a clearer idea of what was going on. It is clear from this that Chalmers and his supporters were not out to reform the law - they were out to set it down. In doing so, they created a statute which "governs the life of a note from its very creation, until its extinction on its return to its maker. . . Not content with that, the Act even holds out hope of resurrection." 13 In the process there were some slight adjustments made to make the law more workable. ${ }^{14}$ It is the method used to introduce these changes that is interesting. Chalmers openly acknowledges his debt to Sir Farrer Herschell, afterwards Lord Chancellor and whose chambers Chalmers had entered in 1875 . He had strong business connections and was, himself, a member of the Commons committee which tinkered with the Bill. It was Herschell who had encouraged Chalmers to take up codification in the first place and he insisted, in Chalmers' words, that it be introduced in a form which "did nothing more than codify the existing law, and that all amendments should be left to Parliament". Chalmers states that he followed this advice rigorously, using his own judgment only where the common law was unclear or incomplete: "in drafting the Bills of Exchange Bill my aim was to reproduce as exactly as possible the existing law, whether it seemed good, bad, or indifferent in its effects". ${ }^{15}$

The philosophy behind this conservatism was frankly political. Here was a Bill, although modelled on Chalmers' own Digest, which had really been set on the road to Parliament in 1880 when he read a paper on negotiable instruments before the Institute of Bankers. That Institute, in concert with the Associated Chambers of Commerce, instructed Chalmers to prepare a draft and, no doubt, paid him for his labors. It then was introduced into the Commons by the President of the Institute. Clearly, there must be no accusations of self-interest and the best way around that possibility was to state that this was merely a code gathering together what had gone before. As Chalmers, himself, states (seemingly without disingenuity) in his own account of the codification: ${ }^{16}$

I am sure that further codifying measures can be got through Parliament, if those in charge of them will not attempt too much, but will be content to follow the lines laid down by Sir Farrer Herschell. Let a codifying Bill in the first instance simply reproduce the existing law, however defective. If the defects are patent and glaring it will be easy to get them amended. If an amendment be opposed, it can be dropped without sacrificing the Bill. The form of the law at any rate is improved, and its substance can always be amended by subsequent legislation. If a Bill when introduced proposes to effect changes in the law, every clause is looked at askance, and it is sure to encounter opposition.

12. Great Britain, Parliamentary Debates, 1882 (3rd series), vol. 272, p. 1671; supra, n. 8, p. xlvii; Sir John Barnard Byles, A treatise of the Law of Bills of Exchange, Promissory Notes, Bank-Notes and Cheques (14th ed. by Maurice Barnard Byles and Archie Kirkman Loyd; London: H. Sweet and Sons, 1885), p. vii.

13. Comment by Stephen A. Scott on Benjamin Geva, "Reflections on the Need to Revise the Bills of Exchange Act”' (1981-82) 6 Canadian Business Law Journal 331 at 331.

14. Byles lists the 16 (or less, depending on how you arrange them) major changes. Supra, $n$. 12, p. vii-ix.

15. Both quotes in supra, n. 4, p. 126.

16. Id., p. 128-9. 
One cannot resist the suspicion that the two of them knew perfectly well that the only members of Parliament capable of understanding the Bill in the first place were those who dealt with negotiable instruments in their own line of work - that is, businessmen and bankers, the very parties who had everything to gain from the enshrinement of their own personal type of currency, kept safe from the usual common law and equitable defences applying to ordinary contracts.

This is not to accuse either Chalmers or Herschell of bad faith but to recognize them as proponents of the earlier, more benign, "what's good for General Bullmoose is good for the U.S.A." school of commercial thought extant at least to some extent among all late nineteenth century British reformers. Chalmers, himself, chides the New York bar for resisting codification, commenting critically that "I cannot help thinking that lawyers sometimes do not quite like their mysteries being divulged". ${ }^{17} \mathrm{He}$ also leaves no doubt that he felt his and Herschell's method produced a better bill. To this end, he quotes Frederic Harrison, a Positivist and practising lawyer who had served on royal commissions on trade unions and law digests: ${ }^{18}$

\begin{abstract}
A Bill usually goes into Parliament in the state in which it ought to come out, and comes out in the state in which it ought to go in. An ordinary statute differs from an ordinary deed, much as a marriage settlement prepared by a competent lawyer differs from one which should be finally settled in a dozen fierce wrangles between the heated relatives of the happy pair. If testators when making their wills were to put in new clauses on the spur of the moment, or the respective families were to cut about the drafts of an eminent conveyancer, wills and settlements would have a strong resemblance to modern Acts of Parliament.
\end{abstract}

It would seem, if longevity and widespread application are the proper tests, that Chalmers' and Herschell's approach was the right one. By 1909, the British Bills of Exchange Act had been enacted with only slight adjustments for local variations throughout the dominions representing the old British Empire. ${ }^{19}$ India was the major exception and, as we have seen, that was because it had earlier enacted the same law in another form. The United States also based its Negotiable Instruments Law (1896) on the British code. The code was also a success in terms of establishing itself as the starting point in terms of the law of bills of exchange. In explaining how a compendium of the law differed from a code, Chalmers wrote in the introduction to the third edition of his Digest (1890): ${ }^{20}$

\footnotetext{
... the general propositions of the Digest could only be considered as law, in so far as they were correct and logical inductions from the decided cases which were cited as illustrations. Now the position is reversed. The cases decided before the Act are only law in so far as they can be shown to be correct and logical deductions from the general propositions of the Act. The illustrations, therefore, must always be tested by the language of the Act itself.
}

17. Id., p. 131 .

18. Id., p. 133.

19. For a list with dates, see J.D. Falconbridge, The Law of Negotiable Instruments in Canada (1st ed.; Toronto: Ryerson, 1923), p. 5.

20. Supra, n. 8, p. xliii. 
A year later, the decision of Lord Herschell in Bank of England v. Vagliano Bros. wrote this philosophy into the case law. ${ }^{21}$ I will now turn to a discussion of the legal rights and processes the Act was meant to enshrine.

\section{MERCHANT-MADE LAW}

I have neither the space nor the patience to go into a detailed legal history of the common law of bills of exchange, promissory notes and cheques. Fortunately, that job has already been accomplished by $\mathrm{J}$. Milnes Holden in The History of Negotiable Instruments in English Law. ${ }^{22}$ Grant Gilmore tells us we really need not look farther back than the beginning of the Industrial Revolution to find the origins of our current law of negotiable instruments ${ }^{23}$ but while that may be true regarding modern application of the rules in the modern (i.e. nineteenth and twentieth century) commercial setting, it is easier to understand the statute if we have some grasp of how these rules originated. Edward Jenks, in an article appearing eleven years after the codification, deplores the lack of knowledge displayed in the courts regarding the origin of negotiable instruments. At most, he complains, "[w]e are favoured with the stock quotations from Cicero and the Pandects (which it is agreed have nothing to do with the matter), with the dicta of Pothier and Heineccius." ${ }^{24}$ Benjamin Russell, in letters written to the Toronto Mail in 1890 in support of the adoption of the Act into Canadian law provides us with an example of what Jenks is complaining about: ${ }^{25}$

As it was long ago finely said by Mr. Justice Story in the supreme court of the United States, "the law respecting negotiable instruments may be truly declared in the language of Cicero, adopted by Lord Mansfield, to be in a great measure not the law of a single country only but of the commercial world; non erit alia lex Romae, alia Athenis, alia nunc, alia posthac; sed et apud omnes gentes et omni tempore, una cademque lex obtinebit".

Russell, a man with more taste for legal pedantry than talent for basic grammar, ${ }^{26}$ describes these words "of the great American jurist" as "nothing more than the plainest common sense". ${ }^{27}$

We know much more, now about the commercial history of negotiable instruments, largely due to Raymond de Roover's classic, $L$ 'Evolution de

21. [1891] AC 107, at 145.

22. J. Miles Holden, The History of Negotiable Instruments in English Law (London: The University of London, The Athlone Press, 1955).

23. "Formalism and the Law of Negotiable Instruments" (1979) 13 Creighton Law Review 441 at 446-7.

24. Edward Jenks, “On the Early History of Negotiable Instruments" (1893), 9 Law Quarterly Review 70 at 70 . See also a similar comment by Frederick K. Beutel, "The Development of Negotiable Instruments in Early English Law" (1938) 51 Harvard Law Review 813 at 813 regarding the tendency among lawyers and judges to confuse assignment and negotiation due to their ignorance of the historical origins of the two terms.

25. Benjamin Russell, A Commentary on the Bills of Exchange Act (Halifax: McAlpine Pub. Co., 1909), p. iv-v.

26. Witness: "A single illustration taken at random will serve to show the way in which our statute has grown up and the purely fortuitous character of the peculiarities to which 1 have inferred." Ibid., p. v-vi. Russell lectured on Bills and Notes at Dalhousie Law School for over twenty years.

27. Id., p. v. 
la lettre de change. $X I V e-X V I I I e$ siècles. ${ }^{28}$ For those unwilling to plough through Holden and de Roover, an adequate understanding of the topic can be obtained from Sir William Holdsworth's $A$ History of English LaW $^{29}$ and for those unwilling to make even that commitment, Plucknett gives you the major points in less than six pages. ${ }^{30}$

The basic point that I want to make regarding the history of bills of exchange finds inspriation in an article by R.S.T. Chorley regarding the tension between the need for certainty on the part of lawyers and the need for flexibility on the part of businessmen. ${ }^{31}$

\begin{abstract}
A usage might alter several times with developing methods of business, and so long as the existing usage was not challenged and thereupon declared by the Courts there would be no difficulty, but so soon as there is a decision the usage becomes stereotyped in law as it stands at that particular moment, and, as it may well alter in fact, the unscrupulous businessman is given an advantage over his neighbour, for he may take advantage of the technicality and contend that this contract has not been carried out by the other party. The merchants are up to a point privileged to be law makers, but unlike most others who have that power, when they have once made a law they can neither repeal nor alter it.
\end{abstract}

I would now like to discuss briefly the law the merchants made in regard to bills of exchange; reference to the problem of dealing with the rigidities brought on by codification will be discussed later.

Let us start by forgetting about the instruments the Bills of Exchange cases mostly deal with today - that is, cheques and promissory notes and look at the function of the classic nineteenth century bill of exchange. I have found no description better or more concise than that of Bertram Jacobs: ${ }^{32}$

The object of a bill of exchange (and of its offshoots, the cheque and promissory note) has been described as "to settle a debt in manner most convenient to the parties concerned". Its two principal uses may be exemplified thus: B owes A, A owes C. Instead of $B$ making payment to $A$, and A making payment to $C, A$ "draws" upon $B$ in favour of $C$, i.e., $A$ orders $B$ in writing to pay $C$ what he $(B)$ owes $A$. B undertakes to comply with this order, such undertaking being expressed on the document by $B$, who thereupon becomes liable to $C$ if $C$ is given possession of the document. $C$ is thus enabled to obtain payment from B, who upon payment discharges simultaneously his own debt to $A$ and $A$ 's debt to $C$.

Again, $Y$ may owe $X$ and $X$ may desire to give $Y$ six months' credit, but not be in a position to forego the present use of the money. He may satisfy both himself and $Y$ by "drawing" upon $Y$, i.e., obtaining a bill from $Y$ containing $Y$ 's present undertaking to pay in six months the then holder of the bill. $X$ may then (if $Y$ 's credit be good) "discount" the bill, i.e., get $Z$ to purchase the bill for the amount of it less a sum to remunerate $Z$ for the six months which he will have to wait before he gets his money back and for the risk $Z$ runs in not getting paid through the possible insolvency of $X$ and $Y$. "Thus a bill of exchange performs two kinds of offices in commerce: it saves the transmission of coined money, and it enables creditors not only to fix down debtors to a day of payment, but to get the use of a sum equivalent to the debt (less a small discount) before it is properly due".

28. (Paris: Librairie Armand Colin, 1953). See also Corrado Marciani, Lettres de change aux foires de Lanciano au XVIe siècle (Paris: Ecole Pratique des Hautes Etudes, 1962) which reproduces 443 bills of exchange.

29. vol. VIIl (2nd ed.; London: Methuen, 1937), p. 113-77.

30. Theodore F.T. Plucknett, A Concise History of the Common Law (4th ed; London: Butterworth and Co., 1948), p. 626-31.

31. "The Conflict of Law and Commerce" (1932) 48 Law Quarterly Review 51 at 63.

32. A Short Treatise on the Law of Bills of Exchange, Cheques, Promissory Notes, and Negotiable Instruments Generally (2nd ed.; London: Sweet and Maxwell, 1924), p. 49-50. 
It is the first of these offices that the bill was originally established to perform and it is here that we must take a quick look at the medieval development. The most obvious antecedent of the modern bill is the medieval device of the cambium which is a document in the form of a promise to pay the bearer. It most frequently took the form of a contract whereby $R$ agreed with $S$ to transport specie from one place to another. Given the obvious dangers of carrying cash through lawless territories, it is not surprising that as trading systems became more sophisticated, these evolved into lettres de change whereby series of traders indebted to one another merely settled the differences by keeping accounts on slips of paper. These bills were not, however, negotiable in nature. That is, while $A$ in Leeds could instruct $C$ in Cádiz (to whom $A$ owed money) to collect from B also in Cádiz (who owed A money), if B failed to pay C, C had no right to proceed on his own but must press his own case with $A$. If there were arguments between $\mathrm{A}$ and $\mathrm{C}$ as to the contract underlying the transfer of funds, A might hold up payment for some time. Or if A failed financially, $\mathrm{C}$ would have to pursue $\mathrm{A}$ as a regular creditor.

This problem was solved by the mid-seventeenth century by adding to the exchange capabilities of the cambium, the negotiability inherent in an earlier, not necessarily mercantile, document the origin of which seems much more obscure. Under these documents, a party placed himself under liability to pay or perform something to (a) a creditor or the creditor's nominee producing the document, (b) a nominee of the creditor producing the document, or (c) simply the producer of the document. Basically, then, these allowed a creditor to assign the benefit of an obligation due him to a third party. These documents did not necessarily - and possibly at first did not at all - involve money. As an example from the year 1036, Holdsworth cites the case of a man who by his will left the guardianship of his wife to his kinsmen or to whomever produced the will. Thirty years later, a third party appeared in court as her guardian and was accepted as such without question upon producing the document. ${ }^{33}$ The combination of the two types of document produced one that operated virtually as a species of currency among merchants. ${ }^{34}$

The advantages are obvious. Once $C$ receives A's bill to collect from B, $\mathrm{C}$ can do so. Even if A's bill sets a later date for collection that is no problem. If, in the meantime, A discovers that the raw wool $\mathrm{C}$ has shipped from Cádiz is of inferior quality, A can do nothing to stop payment by B to $C$. Likewise, should $B$ find out that the bolts of woolen textiles that $A$ has sent from Leeds leave something to be desired, he must (if he has accepted the bill - that is, has agreed to comply with A's order to pay C), pay on the date it falls due. While any and all arguments are being carried on regarding the wool and textile contracts, $C$ holds the cash, or the right to it. It is easy to sympathize with C's position when the argument regarding the quality of goods is between A and B but why should C's position be saf eguarded when he may, in fact, be the culprit? The simple answer is that he may have endorsed the bill to $D$ who brought the wool down from La Mancha and who has, in turn, endorsed the bill to E, a land-owner

33. Supra n. 29 at 116.

34. See the detailed discussion of the marriage of these documents in ibid., p. 113-46. 
there. $\mathrm{E}$ has discounted it (in essence, borrowed on it) back in Cádiz to $\mathrm{F}$, the representative in Spain of G (a rival woolen manufacturer of A's in Leeds) which happened to have some cash lying idle in Valdepeñas that it decided to put to profit. If everyone had to wait for the legalities of everyone else's contract to be settled, the bill would lose its value as currency.

Clearly, merchants were, in the main, willing to put up with any inconveniences of the system in order to take advantage of the considerable conveniences. But problems arise, as Chorley points out, when mercantile usage seeks protection from the law. The gradual accommodation of law and merchant custom to one another is what Holden's book is about and he goes in detail through all the types of problems that could and did arise. The hypothetical situation I have sketched out above is really a very simple one involving only issues regarding the rights and obligations of the drawer (A), payee (C), drawee (B), acceptor (B), endorser (an unclosed class starting with $C$ ), endorsee (an unclosed class starting with D), and the holder in due course (the negotiable instrument term for a bona fide purchaser for value without notice). In addition to these relationships, the law had to take into account situations involving theft of the bill, fraudulent negotiation, holders who gained the property in the bill without giving any consideration, moneys paid out in mistake, viability of bills which had lapsed, and so on. To show just how uncomplicated my scenario is, I offer the facts of Ancher v. Bank of England ${ }^{35}$ which involved a restrictive endorsement. According to Holden, ${ }^{36}$

A bill of exchange had been drawn by $A$ upon $B$ payable to $C$ or order. $C$ indorsed it as follows: "The within must be credited to Captain Dahl, value in account." Later a forged indorsement, purporting to be that of Dahl, was made in favour of Muller or order. Muller indorsed the bill and took it to the Bank of England where it was discounted for him. Muller then absconded. B, the drawee, had accepted the bill but became insolvent. A third party, F, who was a friend or agent of A, the drawer, came to the Bank of England and paid the bill for the honour of A. The forgery was discovered, and an action was brought by $A$ (who thereby "adopted the payment by $F$ and made him his agent") against the Bank for money had and received on the ground that the money paid by $\mathrm{F}$ was paid by mistake.

In the end, A won because it was held to be the Bank's own fault for having taken a bill that was not negotiable. ${ }^{37}$

But the difficulties in the courts came not just because of complicated fact situations but because of real problems of law. As Holdsworth points out: ${ }^{38}$

How the negotiable characteristics of these instruments can be reconciled with legal principle is a matter upon which there has been much speculation. Such specualtion is outside the sphere of legal history; but I think that the history of their growth would seem to suggest that these characteristics cannot be explained by reference to the principles solely applicable either to the law of property or to the law of contract. It suggests rather that they are a judicious mixture of those parts of the principles underlying both these bodies of law, which are the most favourable to safe, easy, and rapid circulation. If we look at the law of property we see that there is no difficulty in assigning property, provided that the assignor has a good title. But "nemo dat quod non habet". If we look
35. (1781) 2 Doug. 637.
36. Supra n. 22 at 120.
37. Id., p. 121.
38. Supra n. 29 at 145-6. 
at the law of contract we see that there is no difficulty about the binding force of a contract to convey another person's property. The promiser is obviously bound personally if he chooses to make such a contract. But difficulties begin when we attempt to assign the benefit of a contract. The negotiable instrument avoids both the proprietary and the contractual difficulty by a judicious mixture of principles taken from both these branches of law. It borrows from the law of property the easy method of assignment by means of an indorsement and delivery, or a delivery merely of the instrument. It borrows from the law of contract the principle that the person primarily liable is personally bound by his contract to pay the indorsee or bearer producing the bill; and that, therefore, no defence, which he might have had to claims by other persons, and no question of title to the bill, can be any answer to an indorsee or bearer producing the bill, who has acquired it in good faith and for value. In addition, it borrows from mercantile custom the principle that, normally, good faith and value will be presumed.

Two principles were vital to the efficient functioning of the merchant system of credit exchange. One was what Gilmore calls "the good faith purchaser idea", that there was no duty to inquire as to past transactions. When one took a bill, one did so free of both the underlying contract defences and any outstanding equities of ownership. Gilmore dubs the other principle "the merger idea", that the paper on which the bill or debt was printed was to be treated as if it itself were the claim or debt it evidenced. This gets around the whole problem of assignment of debts where the assignor may have mistakenly or fraudulently assigned the same debt to more than one party. When possession of the paper is equivalent to possession of the assignment, only the holder has any rights on it, period..$^{39}$ Once these two points were recognized in law, ${ }^{40}$ the rest of the rules that eventually made up the one hundred sections of Chalmers' code were just police to make sure the main two functioned properly. Holden carefully outlines this development of the protection of negotiability and shows how the case law was in turn codified in the Bills of Exchange Act. I here present a not untypical example to show the lengths to which the courts were willing to go to safeguard the integrity of these bills as a form of currency. Section 29(3) of the Act states:

\footnotetext{
A holder (whether for value or not), who derives his title to a bill through a holder in due course, and who is not himself a party to any fraud or illegality affecting it, has all the rights of that holder in due course as regards the acceptor and all parties to the bill prior to that holder.
}

It is derived from the case of Mayv. Chapman. ${ }^{41}$ There it was held that where a bill, affected by some fraud or illegality, is transferred to a bona fide holder and he transfers it to a party knowing of the fraud or illegality but not a party to it, that the transferee gets all the rights the transferor had. The rationale behind this was that, had the bona fide holder to make sure that his transferee were innocent before he transferred the bill, he would be prejudiced in his ability to dispose of the instrument.

The system was of great use to English merchants in their business dealings at home and abroad. It allowed money to change hands without the transfer of specie. At the same time, it was a type of bill free from

39. Supra n. 23 at 448-51.

40. For a case upholding the first see Collins v. Martin (1797), 1 B \& P 648 and for the second see Peacock v. Rhodes (1781), 2 Doug. 633.

41. (1847), $16 \mathrm{M} \&$ W 355,8 LTOS 369. 
government taxes..$^{42}$ It also served as a good form of advertisement, particularly in the days before trade publications. ${ }^{43}$ And as time passed, it became a system of short-term credit fundamental to the functioning of the trade system. This is the second office described in the quote from Jacobs outlining the two functions of the bill of exchange. It started out as a poor step-sister to the first but by mid-nineteenth century, it would be the more prevalent, thanks (according to Gilmore), to "the novel idea of lending money to poor people" '.44 The law so carefully evolved to protect a custom developed by merchants for their own convenience would be turned to other purposes and the bills themselves would become largely instruments of credit. As we have seen in the section of this paper on the history of the codification, it was bankers as well as businessmen who pushed for a rationalization of the law relating to negotiable instruments.

\section{THE BILL OF EXCHANGE AS AN INSTRUMENT OF CREDIT}

This paper does not pretend to offer a history of the rise of credit institutions. For that the reader is directed to works on the history of banking in England. ${ }^{45}$ Instead I want to look at the "credit madness" that took hold of England during the Industrial Revolution and to explain where the bill of exchange fits into all this. In doing so, I hope to shed some light on the peculiar economic and commercial world into which the 1882 Act was born.

Why, after carefully developing a system of payment over half a millenium - a system innately tied to the whole process of doing business - should the commercial class want this system (which it must have known like the back of its hand) written down? The law was already there, after all, in the cases and a scattering of enacting statutes. If anything, codification would, as Chorley points out, only increase the risk of rigidity and also, one might add, the ease of Parliamentary amendment, perhaps to the merchants' detriment. The answer is suggested by the fact that it was the bankers who put the pressure on for the codification of bills of exchange. Merchants were brought into the representation through the Council of the Associated Chambers of Commerce but the truth was that matters had gotten out of merchant hands years before.

Let us briefly consider Jacobs' second type of bill. It is late autumn in Yorkshire. Y, a woolen manufacturer wants to buy raw wool in order to proceed with his winter line of textiles. He wants to start immediately so that his bolts will be able to get to Chile and Argentina in time for autumn there next February. He is short of cash because woolens are just beginning to move in Britain in anticipation of winter and retailers have not yet begun to pay him on their accounts for his summer production.

42. This would not last forever. Between 1867 and 1876, the Canadian Parliament enacted five bills to do with bills of exchange, mostly involving the imposition of stamp duty. See C.P. Davidson, A Compilation of the Statutes passed since Confederation relating to Bills and Banking (Montreal: The Gazette, 1876).

43. A point made by Roy A. Foulke, The Commercial Paper Market (New York: Arno Press, 1981; reprint of New York: Bankers Pub. Co., 1931), p. viii.

44. Supra n. 23 at 452.

45. For example, P.L. Cottrell and B.L. Anderson, Money and Banking in England: The Development of the Banking System, 1694-1914 (Devonshire: David and Charles, 1974). 
He expects to be able to collect these accounts within the next few months. $\mathbf{X}$ is a wool importer. He has purchased large quantities of wool from the spring shearing in Australia and the shipment is due in to Liverpool shortly. X will have to pay the balance on that wool when it comes in. He is short of cash because he is already on the lookout for next spring's production (only a few months away) of wool from Spain. $X$ and $\mathrm{Y}$ want to do business; both are reputable businessmen; both are short of cash. $\mathrm{Z}$ has large agricultural holdings north-east of Leeds. His crop has been taken off and sold and he will not need the money he has on hand until spring planting. $X$ draws a bill on $Y$ for $£ 500$, to be paid in three months. Then, to get the cash he needs now, he sells the bill to $Z$ for $£ 490$ (this is called discounting). $Z$ collects $£ 500$ from $Y$ in the spring. $X$ gets his wool; Y pays for his imports in Liverpool; and $Z$ makes $£ 10$ on cash that otherwise would have spent the winter hidden under the loose brick in his hearth. Such cyclical problems of cash flow - sometimes too little but at other times too much lying idle - were chronic in the commercial system.

It is crucial to this system that $\mathrm{X}$ and $\mathrm{Y}$ be solvent. More so, like Caesar's wife they must be above suspicion. $Z$ has recourse under the law against them both but this will be little comfort to him should $X$ and $Y$ fail financially. It is also possible that the bill will pass to another party. Perhaps $M$ has a prime piece of turnip field to sell and $Z$ endorses the bill to $M$ to pay for it. Or perhaps $Z$ re-discounts the bill to $N$ for $£ 485$ in order to buy the land from $M$. Just as the three-party bill we saw earlier can get very complicated, so can the "simple" two party bill here. Still, before the rise of banking, this form of credit was vital to the development of British industry. Since a holder in due course had recourse against all and any names appearing above his own on the bill, he only had to be able to recognize one that he thought would be good for the money. This is a workable system so long as merchants are a small, interrelated brotherhood; as commerce expands - into different parts of the world and into different fields of endeavor - it becomes more difficult for endorsers to rely on their own information and judgment. A class of specialists grew up to provide information and to get those who had short-term superfluity of money together with those who could put it to use in the interim. These specialists would soon cease to act simply as bill brokers and would begin to discount bills on their own. In time, the bills themselves would also change: they would frequently have little to do with merchants at all.

The shift away from the bill meant purely to facilitate trade had become evident by the end of the seventeenth century. By that time, another type of instrument - the promissory note - had become negotiable as far as merchants and bankers were concerned. Promissory notes had not at all the same origin as had bills of exchange. They had started out originally during the English Civil War as receipts issued by goldsmiths to customers who had left money with the goldsmith for safekeeping. The receipts took the form of a promise to pay the sum deposited, sometimes to payee or bearer, sometimes to payee or order. Later, they left the goldsmiths' exclusive employ and were used by parties - often merchants, but not always - who wanted a method whereby 
they could promise to pay in the future for goods, services, etc. acquired in the present. The similarity to the two party bill described above is striking and the two were of ten confused. Because of the similarities, merchants saw no reason why these, too, should not be negotiable; because of the confusion, they wanted them to be made negotiable. One did not want to risk becoming transferee of what one thought was a bill only to find it was a note. If it were the latter and were tainted by fraud or some other defect, the transferee's rights were not protected. The question was settled legally in 1704 with the passing of the Promissory Note Act. ${ }^{46}$ The Act was a response to the decision of Lord Holt in Buller v. Crips where he said: 47

.. that this note could not be a bill of exchange, that the maintaining of these actions
upon such notes were innovations upon rules of the common law; and that it amounted
to the setting up a new sort of specialty, unknown to the common law, and invented in
Lombard Street, which attempted in these matters of bills of exchange to give laws to
Westminster Hall. That the continuing to declare upon these notes upon the custom of
merchants proceeded from obstinacy and opinionativeness...

Holt's main objection was that merchants already had the two party bill which they could use. Setting the promissory note on the same footing would open negotiability to non-merchant transactions. The possibility that a non-merchant might be a party to a bill of exchange had only been considered very recently ${ }^{48}$ and Holt was trying to prevent the flood waters from breaking through into a new channel.

But he could not. Negotiability was such a useful concept - and the very one on which merchant credit transfers had been built - that the class of instruments to which it was applicable was bound to expand, not contract. The cheque was always seen as a special type of bill of exchange and therefore negotiable. ${ }^{49}$ This view is directly stated in the definition of a cheque in the Bills of Exchange Act (1882) itself ${ }^{50}$ However, there were increasingly more types of documents appearing whose negotiability had to be decided upon. The merchants had managed to get Holt's decision in Buller v. Crips over-ridden by statute by pleading that merchant usage held promissory notes negotiable. If merchant usage was to be the test, then that must be defined. For years, it was held that to be negotiable an instrument must have been so accepted under mercantile custom since time immemorial. This would wash away under the surge of paper floated on the Industrial Revolution. Crouch v. Crédit Foncier ${ }^{51}$ reiterated the old rule in 1873 but was in short order overturned by Goodwin v. Robarts (1875) which held that negotiable instruments were a clear exception to the general rule that the novelty of a custom precluded its incorporation into the law merchant. ${ }^{52}$ Bechuanaland Exploration Co. v. London Trading Bank (1898) stated that fifteen years was enough time to establish negotiability of debentures as a settled mercantile custom. ${ }^{53}$

\footnotetext{
46. $3 \& 4$ Anne, c. 9 .

47. (1703), 6 Mod. 29 at 30 .

48. In Withersleyv. Sarsfield(1690), I Shaw. K.B. 125.

49. Supra n. 29 at 190 .

50. Bills of Exchange Act, 1882 (U.K.), 45 \& 46 Vict., c. 61, s. 73.

51. (1873), 8 QB 374; 42 LJQB 183; 29 LT 259.

52. (1875), LR 10 Ex. 76 and Ex Ch 337; affirmed by HL 1 AC 476.

53. [1898] 2 QB 658; 67 LJQB 986; 79 LT 270; 14 TLR 587
} 
From the last case, we can also see that expansion of the class came in the type of instruments recognized. By 1896, in Canada, these included bank notes and Dominion notes, foreign government bonds, municipal debentures and corporation debentures (still unsettled). ${ }^{54}$ Generally, over the years, three requirements for negotiability have evolved. Firstly, even if the class is negotiable, the particular instrument will not be if there is evidence on its face to destroy negotibility. Secondly and conversely, it is not sufficient that a certain individual instrument be accepted with all the characteristics of negotiability if it does not belong to a class of instrument considered negotiable (for example, attempts to make negotiable documents of title to goods rather than money have failed). Thirdly, mercantile usage is essential, though it may be short-term and may even be foreign. ${ }^{55}$ Or as one writer put it more succinctly: "Money passes with a good title because it is money; and notes because they are like money; and then a foreign bond because it is like a note". ${ }^{56}$ And so on.

It would seem that as far as merchants and their lawyers were concerned, the universe was unfolding as it should. As one legal writer gloated in $1876: 57$

\begin{abstract}
When Lord Holt, in the year seventeen hundred and three, indignantly denied that promissory notes payable to bearer were negotiable and inveighed against the "obstinacy and opinionativeness of merchants who were endeavouring to set the law of Lombard street above the law of Westminster Hall", he had no prophetic vision of the great part which negotiable instruments were to play in the transactions of commerce, and little dreamed that the struggling idea of Lombard street was destined to develop, expand and diversify itself, until it overspread the civilized globe.
\end{abstract}

But in overspreading the universe, Lombard Street o'erspread itself as well.

Lombard Street is the centre of banking in Great Britain. Due to London's position in the nineteenth century as the trading capital of the world, Lombard Street was banker to the universe. But, although bankers and businessmen may have always maintained that they know more of banking and business than do the courts, they did not then know enough to be able to avoid extremely frightening panics and failures throughout the period of the growth of banking. The bill of exchange was essential to the whole process. And, as I mentioned above, things got out of hand.

Throughout the Industrial Revolution, negotiable instruments expanded not only as to type but in number. There have been many reasons given for the expansion of commercial paper and all are likely true to some extent. At the simplest level, there was a shortage of gold in the nineteenth century. Many countries were storing the metal to back up their currency (for maintenance of the so-called gold standard) and it was

54. See discussion of "Other Negotiable Instruments" in J.J. MacLaren, Bills, Notes and Cheques. The Bills of Exchange Act, 1890 (2nd ed.; Toronto: Carswell, 1896), p. 441-7.

55. Dudley Richardson, Guide to Negotiable Instruments and the Bills of Exchange Act (5th ed.; London: Butterworths, 1976), p. 18-9. This is an excellent handbook.

56. John S. Ewart, "Negotiability and Estoppel” (1900) 16 Law Quarterly Review 135 at 152.

57. John W. Daniel, A Treatise on the Law of Negotiable Instruments (5th ed. by John W. Daniel and Charles A. Douglass; New York: Baker Voorhis \& Co., 1903). Preface to 1st edition, $\mathrm{p}$. ix-x. 
in short supply. Not until the rushes in Australia, South Africa and California at the end of the century could currency tied to gold increase to any extent. There has been much debate about the nexus between the shortage of hard cash and Britain's Great Depression in the last quarter of the nineteenth century and clearly the negotiable instrument as an alternative to cash plays a role in this complicated discussion. For our purposes, we need only function at a basic commonsense level: businessmen had to transfer credits somehow and, if there was no cash, another device was needed. The obvious device was the old "outland" bill - the bill involving foreign trade described above.59 "Inland"' bills of exactly the same character had been accepted by English law by the second half of the seventeenth century. ${ }^{60}$ With money tight, even the smallest merchant might have to turn to bills to do his daily business. In the second half of the eighteenth century, bills for as little as one shilling were in circulation. This was remedied by a statute outlawing bills for less than twenty shillings and placing penalties on those for less than $£ 20.61$ Statutory controls on such small bills were aimed at keeping the production of currency firmly in the control of the government through its monetary arm, the Bank of England. But the real threat to the hegemony of the Bank came not from small bills doing endless rounds in obscure counties to settle debts among numerous petty merchants but from what came to be known as accommodation paper. This was sparked not by a shortage of cash but by a shortage of credit.

Industrialization requires capital. We have already seen that the two party bill can be used to shift capital in the short term from one businessman to another. ${ }^{62}$ Bill brokers handled this shift before the growth of banks. They made it their business to know the worth of businessmen and to make the deals. By the time country banks began to increase in number - they grew from about twelve in 1750 to 721 in 1810 - the brokers had such good contacts in London that they took over discounting for the banks as well. By 1810 , brokers handled approximately $£ 10,000,000$ in bills annually for the country banks. ${ }^{63}$ This was an era of speculation mania. Not only were the new South American republics being "developed" by means of money raised on English bills but schemes such as one to drain the Red Sea to retrieve the treasure lost by the Israelites during their flight from Egypt managed to find funding. ${ }^{64}$ Not surprisingly, there was a crash in 1825 with the resultant attempt to

58. See S.B. Saul, The Myth of the Great Depression, 1873-1896 (London: Macmillan, 1969), p. 16-27.

59. Supra, text after n. 34 .

60. According to J. Marius, Advice concerning Bils [sic] of Exchange (London, 1656), The Payment of Bills Act (1698) 9 Will. 3, c. 17 put outland and inland bills on the same legal footing. Marius's work is discussed at length by Holden (in supra, n. 22) as is that by G. de Malynes, Lex Mercatoria (London, 1622).

61. Negotiation of Instruments below certain amount (1775) 15 Geo. 3, c. 51. A further act in $1777(17 \mathrm{Geo} .3, \mathrm{c.} 30)$ put further restrictions on bills for less than $\mathrm{f5}$.

62. Supra, text after $n .45$.

63. W.T.C. King, History of the London Discount Market (new impression of 1st ed., 1936; London, Frank Cass, 1972), at 5-10. This is the classic work on the topic and well worth reading by anyone seeking to understand the law of negotiable instruments.

64. Id., at 35-6. 
straighten out the monetary system. One of the results was the rise of joint stock banking which was required by statute to follow certain guidelines. Rather than undermine the, by now, powerful discount houses, these banks in turn came to depend upon them. The new banks were in keen competition for depositors and therefore had to pay interest. To pay this interest they had to keep their deposits constantly employed and were therefore always on the look-out for bills to buy. They also had to be able to sell bills at very short notice in case of customer withdrawals. Such institutions were clearly acutely susceptible to a run on the bank. ${ }^{65}$ As one banker explained his system: ${ }^{66}$

Our practice is, tlat we have no unemployed money, to send it all to London, and sup. posing an extra demand arises in the country at a higher rate of discount (than in London], we then discount bills in London, or wait their coming into cash, and employ it in the country; and the practice of making notes enables us to carry on both systems, because the time we get by the circulation of the notes enables us to get the London bills paid, so as to meet the extra demand in the country.

In other words, the banks needed a constant supply of bills to stay in business. One way to accomplish this was to buy two-party bills from merchants in need of cash; as the need for bills increased, the banks grew less fastidious about checking out the parties thereto. Their imprudence now appears amazing: it was not uncommon for a bank with a paid-up capital of $£ 50,000$ to have endorsed re-discounts of $£ 1,000,000,000$ at one time. ${ }^{67}$ But there was nothing illegal about this "accommodation" paper ${ }^{68}$ and the bankers felt themselves sufficiently protected by the numbers game. As one writer pointed out: 69

\footnotetext{
... a holder of a bill of exchange can bring actions at one and the same time against every party whose name is attached to it, and in the event of the failure of them all, can prove upon the estate of each for the full value of the bill. Thus if there be six parties on it, and he receives upon the average $3 \mathrm{~s} .4 \mathrm{~d}$. in the pound from each estate, he is paid his whole debt. He is in fact permitted to prove six hundred pounds, where other creditors can prove only one . . . With a sufficient number of names upon it, a bill may therefore be a good security for money advanced upon it though all the parties to it may in reality be insolvent ... A system of bill accommodation can never be long pursued without the banker not being aware of, but accessory to it, and thus the law in effect encourages a species of fraud between the banker and his customers, which there would be more propriety in its endeavour to prevent.
}

It was not a long step from here to outright frauds such as seeking out a person with a name identical or nearly so to that of a well-known merchant house and inducing him to "accept" bills in handwriting similar to that of his namesake. ${ }^{70}$ Clearly, the reputable houses wanted to stay clear

65. Id., at 39-45.

66. Charles S. Forster of Walsall, id., at 45.

67. Id., at 93.

68. It is provided for by s. 28 of the $1882 \mathrm{Act}$.

69. T. Joplin, Examination of the Report of the Joint Stock Bank Committee (2nd ed. Ridgeway 1837) at 17-18. Quoted in supra n. 63, at 93n. It should be noted that some bills had as many as 120 endorsements, id., at $31 \mathrm{n}$.

70. Id., at 135 . 
of such accommodation paper: what they wanted were good solid merchant bills based on actual commercial transactions. ${ }^{71}$ But as the Governor of the Bank of England lamented in 1858, it was impossible to detect accommodation paper ${ }^{71 a}$

... except by knowing the Iransactions of the parties, and using your best discretion in deciding whether the bill is legitimately drawn by one in such trade upon another; you only form the best opinion you can; you cannot actually fathom or discover that it is or is not an accoınmodation bill.

I started out this section with the query: why codify a five hundred year old system that merchants had worked out and knew perfectly well? I have attempted by the above abbreviated discussion of credit abuse in the nineteenth century to show that the old merchant bill of exchange while still extant - had been shunted aside by accommodation paper frequently not backed by any viable commercial transaction whatsoever and often operating at a level only slightly above fraud. The bills represented not actual obligations that could be paid as soon as someone's ship came in but were rather floated on the lending of one party's name to another for credit purposes. In this, an accommodation signature operated somewhat as does that of a guarantor for a loan but that is usually done in official surroundings, involves only the borrower, the lender (usually a bank) and the guarantor and everyone, at least theoretically, knows about everyone else's affairs, in particular the one underlying the document. But the whole purpose of the bill of exchange was to get away from the need to depend on fair dealing, etc. in the underlying contract. The protection it offered was now being widely abused. Cases came constantly before the courts and merchants felt the need as never before to know the law of their own creation. As a Canadian textbook for business students pointed out, promissory notes and bills of exchange were the commonest form of contract. Furthermore, whereas other contracts were usually drafted under the guidance of a solicitor, these were not and the businessman should be able to deal intelligently and safely with them under all circumstances. ${ }^{72}$

There could be no question of returning the bills to their former status by restricting them, as they were in France, to instruments designed only to transfer funds over a long distance. ${ }^{73}$ Matters had simply gone too far; bills had "for many practical purposes, become an equivalent to, and

71. This is still the case. "The kind of bill a banker likes has its origin in an actual commercial transaction - say the export of Australian wheat to England - which will bring money into the hands of the debtor automatically at the end of a very short period of, say, three months. The banker simply has to sit back in his parlour for the very short time while the wheat is coming across to England, and the debtor will meet his bill without the slightest difficulty, provided, of course, that the debtor is an honest man - and the banker looks for reputable names on the bill to guarantee that he will receive in due course the money that is bound to emanate from the conclusion of the transaction. R. S. Sayers, Modern Banking (6th ed. Oxford; Clarendon Press, 1964) 183. Emphasis his.

71a. Sheffield Neaves, quoted in supra n. 63, at 177n.

72. J.W. Johnson, Promissory Notes, Bills of Exchange, Cheques and Other Negotiable Instruments, a Reference Book for Business Men and a Text Book for Commercial Students (9th ed.; Belleville: Ontario Business College, 1903) 6. For a similar guide for notaries see John H. Macleod, Negotiable Instruments and the Bills of Exchange Act (Vancouver: The Society of Notaries Public of British Columbia, 1936).

73. Supra n. 8, at lviii-lix. 
representative of, money". ${ }^{74}$ The British economy, geared by 1880 to sell to the outside world the output of one worker in five, ${ }^{75}$ could not undermine one of the bases on which it was standing. This, then, is one explanation of the passing of a Bills of Exchange Act in 1882: merchant fear that the lex mercatoria was fading in recognizability and the desire to have it put down in writing. ${ }^{76} \mathrm{~A}$ related reason is that law itself was becoming more technical and rigid. As one prominent business lawyer complained in 1849:77

\footnotetext{
Until shortly after the time when the last Edition of this Treatise was prepared, the questions discussed generally arose simply on the evidence at the trial; but now, for the most part, they are presented through the medium of the pleadings, or are so fettered by them, and mixed up with formal matters and technicalities, as to make it extremely difficult to extract principles, or to abridge the cases clearly and concisely. In addition to this, the cases too frequently suggest questions not resulting from actual transactions, but purely fictitious difficulties invested by the ingenuity of the pleader to stay the progress of the suit. The number of questions, real and unreal, which have thus been discussed since the publication of the last Edition in 1834 , has been so great as to render the reduction of them within a tolerable compass a most arduous task.
}

Bills had also obviously become a mainstay of the English banking system and its needs had also to be taken into account. Both organizations needed legal certainty so as to arrange their affairs. The bankers approached Chalmers and in tandem with the merchant class they got the bill through Parliament. To do so they needed more widespread political support but it is easy to see the attraction of a codification of the merchant law to nineteenth century politicians. From, or recently up from, the merchant classes themselves, they had faith in the value of a fellow merchant's word. ${ }^{2}$ This value was now being undermined by abuse of the system by people on the edge of the merchant class and by sheer inability to know your fellow merchant any longer in the expanding commercial world. Most nineteenth century reforms were enacted with an eye to changing what was "bad" in order to safeguard what was "good". Although a code and not a reform, the Bills of Exchange Act (1882) fits right in.

74. J. Story, Commentaries on the Law of Bills of Exchange, Foreign and Inland, As Administered in England and America with Occasional Illustrations from the Commercial Law of the Nations of Continental Europe (2nd ed.; Boston: Charles C. Little and James Brown, 1847) 19.

75. R.S. Sayers, A History of Economic Change in England, 1880-1939 (London: Oxford University Press, 1967) 13.

76. See Chorley's acerbic observation that "To tell a merchant that if he gets his contracts settled by a lawyer he will be safe, though valuable advice, is hardly likely to increase his already lukewarm regard for the legal system under which he is doing business." Supra n. 31, at 71.

77. Sir John Bayley, Summary of the Law of Bills of Exchange, Cash Bills, and Promissory Notes (6th ed. by George Morley Dowdeswell; London: Benning \& Co., 1849), preface by Dowdeswell, at iij-iv.

77a. For example, see the quote from Adam Smith (The Wealth of Nations) in supra, n. 63, at 5 , regarding the development of the bill as one of "[the] customs of merchants, which were established when barbarous laws of Europe did not enforce the performance of their contracts. . " and the comparison of this vicw with Karl Marx's definition of "bourgeois" in N. MacCormick, Legal Reasoning and Legal Theory (Oxford, Clarendon Press, 1978) 4. 


\section{CONCLUSION}

I started out this paper with a reference to Hegel's proposition that knowledge tends to come at the end of historical periods rather than at the beginning and a promise that I would attempt to make this paper applicable to modern-day trends in law. It is a commonplace that legal change lags behind societal change; the question is how far we should let it hang back before we reform it. The first question to ask is how much does the Bills of Exchange Act have to do with modern commercial reality. The second is what other legal needs might it currently be filling. The third is how our legal institutions should deal with a technical body of law that may serve a function but is almost unintelligible now that it is removed from the historical situation that breathed life into it.

There are still bills of exchange. They of ten bear such romantic titles as cotton bills, steel bills, grain bills, breadstuffs bills, machinery bills, etc. ${ }^{78}$ But it should be clear from those very designations that they are different from the old merchant bills envisioned by the 1882 Act. The "slip" of the early nineteenth century has today become a fully negotiated contract. Companies using them are really not in need of the sort of protection once required by parties having no idea as to the underlying contract giving rise to a stranger's bill. The truth is that the classic commercial bill to finance overseas trade never really recovered from World War $I .{ }^{79}$ At the same time, negotiable instruments legislation is still on the books ${ }^{80}$ and still being litigated. One wonders why, as Gilmore puts it, the law of wampum has outlived the use of wampum. ${ }^{81}$ In fact, Gilmore was so intrigued by his own question that he wrote a later article examining exactly the problem pertaining to my second question.

Gilmore, as mentioned above, ${ }^{82}$ holds that by the time of codification, at least in the United States in 1896, negotiable instruments were almost solely credit devices. The description of the discount market in part IV above gives the background for what he is talking about. But Gilmore sees it as more than just an out-of-date code, he sees it as almost a plot by bankers and puts his finger on one of the abuses that Canada's Act was recently amended to abolish. As Gilmore says: ${ }^{83}$

In this century nothing is rarer than a true negotiation to a third party purchaser for value - the use of negotiable notes which pass from dealer to finance company in an attempt to carry out consumer frauds is hardly a "true negotiation". The whole "holder in due course" concept could usefully have been abolished when negotiable instruments law was codified at the end of the nineteenth century.

78. See the many and various classifications in G. G. Munn, Encyclopedia of Banking and Finance (7th ed. by F.L. Garcia; Boston: Bankers Pub. Co., 1973) 370.

79. For a discussion of the fate of the discount market so fully described by King, see W.M. Scammell, The London Discount Market (London: Elek Books, 1968).

80. And is still - in Canada and elsewhere - strikingly similar to the law in the original code. For example, see W. D. Hawkland, Commercial Paper (Philadelphia: American Law Institute, 1979) regarding Article 3 of the Uniform Commercial Code, and H. E. Yntema and R. Batiza, The Law of Negotiable Instruments (Bills of Exchange) in the Americas An Analytical Statutory Concordance (Ann Arbor: University of Michigan, 1969) for Latin America.

81. G. Gilmcre, The Death of Contract (Columbus, Ohio: Ohio State University, 1974) 9.

82. Supra, text for n. 44.

83. Supra, n. 81, at 108n. 
Part V of the Canadian Act, dealing with Consumer Bills and Notes, attacks just this problem. ${ }^{84}$ Other countries have also had to consider the fact that their negotiable instruments law may be applying the protection necessary for merchant bills in a period before efficient world-wide communication to credit instruments where at least one of the parties knows precisely what is going on. A resurgence of the popularity of commercial and accommodation bills occurred in Australia and New Zealand in the early $1970 \mathrm{~s}^{85}$ With the collapse of the Securitibank Group, a large merchant bank involved in such bills, New Zealand set up a commission to consider reforming its Bills of Exchange Act. ${ }^{86}$ The operative answer to my second question would seem to be, then, that yes, the Bills of Exchange Act does fill a legal purpose, though clearly not that originally envisioned for it.

This brings us to my third question: what should we do about all this? The answer on everyone's lips seems to be reform, reform, reform. This cannot be undertaken lightly. The original bill was only adopted into Canadian law in the first place after considerable debate. ${ }^{87}$ Its application has had to overcome constitutional difficulties ${ }^{88}$ and a colonialist urge to fit in more closely with either Great Britain ${ }^{89}$ or the United States. ${ }^{30} \mathrm{We}$ also seem to have to overcome our awe of Chalmers. As one Canadian writer intoned regarding the original Act, "it seems to me obvious that its amendment is not by any to be enterprized, nor taken in hand, unadvisedly, lightly, or wantonly; but reverently, discreetly, advisedly, soberly, and in the fear of God" ${ }^{91}$ Precisely this type of caution seems to have informed suggestions for reform up to this point..$^{92}$ One can hardly picture Chalmers, himself, treading so lightly. One rather sees him rising before the Institute of Bankers to make the following sort of statement.

The Act applies to three types of negotiable instruments: bills of exchange (or drafts), cheques and promissory notes. In the organization of the statute the bill of exchange is treated as the centre-piece. Ninety-one years later, bills of exchange are no longer the medium of payment in commercial and personal transactions that they once were. To some extent they are used as independent instruments of payment in international trading transactions and in connection with the extension of bank credit by way of

84. Supra, n. 2, ss. 188-192.

85. Supra, n. 7, at 10.

86. See Report of the Working Party on Negotiable Instruments (Wellington, N.Z., 1977).

87. The appendix of D. H. Girouard, The Bills of Exchange Act, 1890 (Montreal: Jos. M. Valois, 1891) at 347-513 takes the trouble to reproduce in full the debates in the House of Commons and the Senate.

88. G. Wassermann, "The Bills of Exchange Act: its application in the Province of Quebec" (1967) Rév. du Barreau de la Province de Québec 653.

89. For example, Falconbridge, supra, n. 19, at 166-176 supports an amendment to bring Canada's 1890 Act back in line with the original 1882 British Act. He even supports an amendment regarding crossed cheques even though he is forced to admit that these figure small in Canadian law.

90. N. L. Goldman, "The Canadian Bills of Exchange Act and Article 3 of the Uniform Commercial Code: A Comparison" (1965) 3 Osgoode Hall L. J. 331.

91. Supra, n. 13.

92. For example, see 1. F. G. Baxter, "The Bill of Exchange as an assignment of funds: A comparative study" (1953) 31 Can. Bar Rev. 1131; H. R. Eddy, The Canadian Payment System and the Computer, Issues for Law Reform (Study paper prepared for Law Reform Commission, Ottawa, 1974); Law Reform Commission of Canada, The Cheque, Some Modernization (1979). All suggest tinkering with the current legislation. 
bankers' acceptances and letters of credit (where, however, the rights of the parties are largely governed by agreements or by special rules of law.) Promissory notes are now used primarily as evidence of indebtedness and not as independent instruments of payment in transactions in which their negotiability is important. Cheques are now by far the most common form of negotiable instrument to which the Bills of Exchange Act applies, and even in the case of cheques, the rights of the parties are governed to a considerable extent by the common law rules relating to the relationship between bank and customer: conversion, mistake, and fraud. Perhaps the lack of interest in amending the Act owes something to these changes in commercial practices over the years. ${ }^{93}$

I think we must take this as our starting point. We must recognize that the world has changed in the past century. It is the only way we can take control of the situation. Without regard to modern commercial reality we are doomed to empty formalism. Perhaps it is time to let loose our own owl. It may not know precisely where we are heading but at least it will have a better idea of where we have been.

93. Gordon Sedgwick in response to Benjamin Geva, supra, n. 13, 344 at 346. 